\title{
A karusszel típusú csalások elleni küzdelem fegyvernemei és azok célpontjai
}

\section{SZABÓ Barna ${ }^{1}$}

\begin{abstract}
A karusszel típusú csalás egyik alaptípusa a tagállami határokon átnyúló, szervezett, általános forgalmi adóra elkövetett csalárd magatartásoknak, amelyek elleni fellépés Magyarország Európai Unióhoz történó csatlakozásával vált aktuális kérdéssé és egyben kihívássá a Nemzeti Adó- és Vámhivatal, valamint jogelödjei számára. Tanulmányom célkitüzése e csalástípus, illetve az ellene történő fellépés adóigazgatási, rendészeti és bűnügyi eszköztárának ("fegyvernemeinek") a bemutatása, valamint az egyes eszközök („,fegyverek“) hozzárendelése a karusszelek müködési mechanizmusát meghatározó releváns elemek felszámolására, befolyásolására irányuló törekvésekhez („célpontokhoz"). Dolgozatom további célja az, hogy felhívjam a figyelmet a körhintacsalás bünügyi statisztikákban történő mérésének a szükségességére, amelynek relevanciája nem csupán a visszacsatolás, hanem az Európai Unióban a közelmúltban ideiglenesen bevezetett általános fordított adózás alkalmazása során is felmerülhet.
\end{abstract}

Kulcsszavak: karusszel típusú csalás, általános fordított adózás, vagyonbiztosítás, bünügyi statisztika

\section{Bevezetés}

A hozzáadottérték-adó (továbbiakban: héa) - amelyet a magyar adózási rendszerben általános forgalmi adóként (továbbiakban: áfa) ismerünk - ötletének az eredete nem tisztázott. Bizonyos ugyan, hogy a koncepciót Wilhelm von Siemens német üzletember munkálta ki 1919-ben, azonban egyes források szerint az elgondolás Thomas Sewall Adams amerikai egyesült államokbeli közgazdász 1910 és 1921 közötti írásaiban is megjelent. ${ }^{2}$ A héa széles körú bevezetésére ennek ellenére 1954. április 10. napjáig kellett várni. Maurice Lauré-nek, a francia adóhatóság vezetőjének a tervei alapján ekkortól kezdték el alkalmazni lépcsőzetesen, először a nagyvállalatoknál, majd később kiterjesztették az egész gazdaságra, végezetül a lakossági szektorra is. ${ }^{3}$

\footnotetext{
SZABÓ Barna, őrnagy, szakértő főnyomozó, Nemzeti Adó- és Vámhivatal Bűnügyi Főigazgatósága Központi Nyomozó Főosztály

Barna SZABÓ Major, Financial Investigator, National Tax and Customs Administration of Hungary Criminal Affairs Directorate General Central Investigation Divison

https://orcid.org/0000-0002-1040-5656; szabo.barna@nav.gov.hu

2 James (2011) 15.

3 James (2011) 16.
} 
Az Európai Unióban (akkori nevén Európai Közösségekben) a mai értelemben vett héa rendszerét az 1977/388/EGK - úgynevezett hatodik - irányelvben fogalmazták meg, amelyet - 29 alkalommal történő módosítására való figyelemmel - a Tanács 2006/112/EK irányelve kodifikált újra. Magyarországon a modern alapelveknek megfelelő héát, áfa néven 1988. január 1. napjától, az 1987-1988-as adóreform keretén belül vezették be. A jelenleg hatályos, általános forgalmi adóról szóló 2007. évi CXXVII. törvény - illetve már az ezt megelőző áfatörvényünk (1992. évi LXXIV tv.) is - maximálisan átvette az Európai Unió szabályrendszerét a Tanács 2006/112/EK irányelvében foglaltak szerint. ${ }^{4}$

Habár a héát napjainkra világszerte mintegy 140 országban vezették be, ${ }^{5}$ múködési mechanizmusa a tagállami határokat átlépő ügyletek tekintetében visszaélésekre ad lehetőséget, amire először az 1970-es évek végén, 1980-as évek elején figyeltek fel a Benelux-államok területén. Tekintettel arra, hogy egyes becslések szerint az Európai Unióban a „héa nélkül keringő” áruk értéke napjainkban évenkénti 1500 milliárd euró nagyságrendű - amely körülbelül 150-200 milliárd euró héabevételnek felelne meg - az ellenük történő fellépés alapvető fontosságú követelménnyé vált. ${ }^{6}$

A fenti kihívásokra válaszul tanulmányom célkitűzése az európai uniós héa-/áfavisszaélések egyik alaptípusának, a karusszel típusú csalásnak, illetve az ellene történő fellépés adóigazgatási, rendészeti és bűnügyi eszköztárának egy sajátos szempontrendszer szerint történő bemutatása. Fel szeretném hívni továbbá a figyelmet bűnügyi statisztikákban történő mérésüknek a szükségességére, amelynek relevanciája véleményem szerint nem csupán a visszacsatolás, hanem az Európai Unióban ideiglenesen bevezetett általános fordított adózás alkalmazása során is felmerülhet.

\section{A karusszel típusú csalás múködési mechanizmusa}

A carousel - vagy ahogyan a magyar nyelv átvette: karusszel (jelentése: körhinta) - típusú csalás a héa/áfa müködési mechanizmusának kijátszására irányuló csalárd magatartások egyike. 


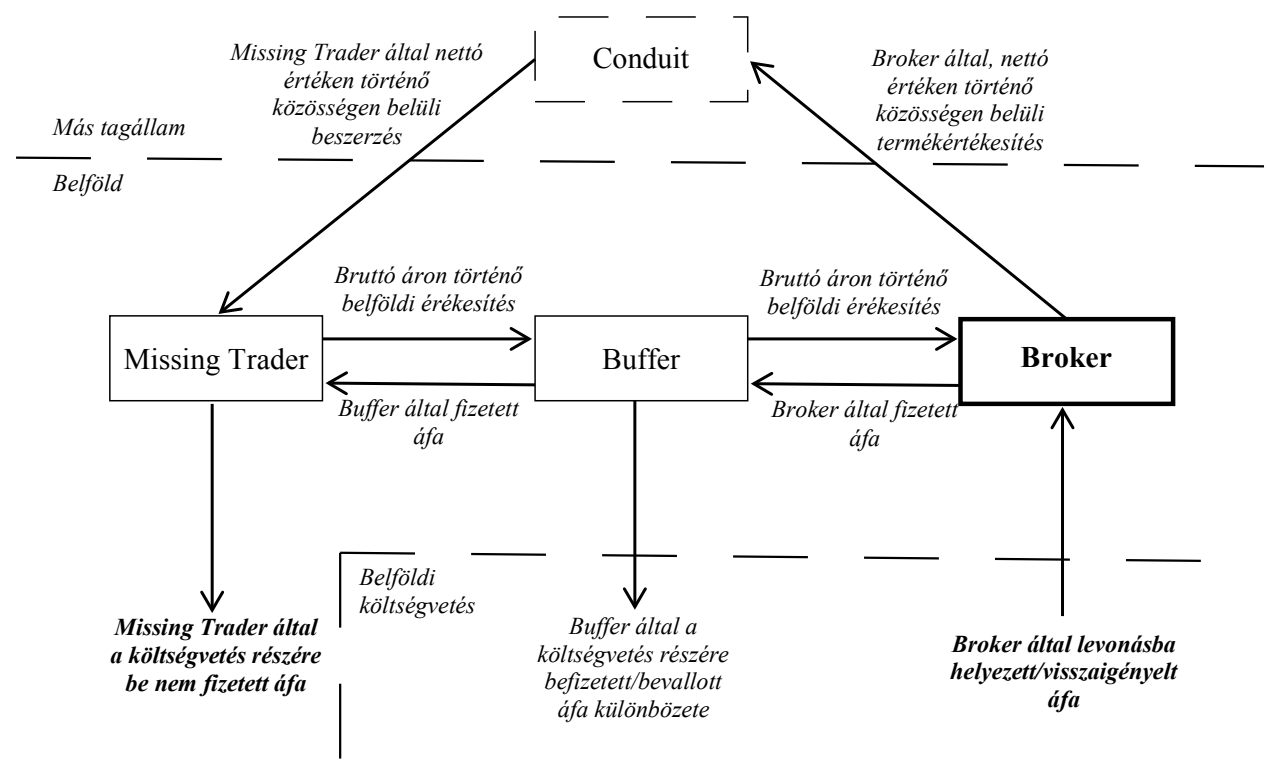

1. ábra: A karusszel típusú csalás folyamata. Forrás: Magyar-Áhel (2012) 86. alapján saját szerkesztés

Mint ahogyan az 1. ábrán is látható, lényege abban áll, hogy a „körhinta” első belföldi eleme (Missing Trader) nettó értékben számlát fogad be egy más tagállamban bejegyzett társaságtól (Conduit) majd közösségen belüli beszerzése, illetve belföldi értékesítése után az áfát nem fizeti be a költségvetésbe, és jellemzően be sem vallja, mindemellett gyakran elérhetetlenné válik a hatóságok számára. A belföldi számlázási láncolat utolsó eleme (Broker) viszont áfamentes közösségen belüli termékértékesítése során a Missing Tradertől közvetlenül vagy más Buffer társaságon keresztül közvetve befogadott költségszámlák áfatartalmát levonásba helyezi, vagyoni hátrányt okozva ezzel a költségvetésnek, további visszaélésekre adva lehetőséget. A karusszelcsalás legfontosabb jellemzője, hogy az ilyen típusú „körhintában” a kereskedelmi ügyleteknek nem kell feltétlenül valós gazdasági tartalommal rendelkezniük, piaci kereslet és tényleges értékesítés mellőzésével - gyakorlatilag laboratóriumi körülmények között, kizárólag fiktív számlák felhasználásával - is müködőképes a mechanizmus. ${ }^{7}$

A gyakorlatban azonban - az 1. ábrán bemutatotthoz képest - a számlázási láncolatok jóval bonyolultabbak és összetettebbek, az érintett gazdasági társaságok száma jellemzően meghaladja a több tízes, nagyobb struktúrák esetén akár a több százas nagyságrendet, és nemcsak „térbeli”, hanem „időbeli dimenzióval is rendelkeznek.

7 Magyar-Áhel (2012) 86-90. 
Az elkövetők ugyanis cselekményük leplezése céljából igyekeznek a hatóságok számára minél felismerhetetlenebb és átláthatatlanabb céghálózatokat létrehozni, ami a rendszer elemeinek rövid időközönkénti cseréjével tovább fokozható.

A 2. ábrán egy valódi, pénzügyi nyomozói szolgálatom során vizsgált feljelentés mellékleteként csatolt karusszel típusú anonimizált láncolatot szeretnék bemutatni, amelynek cégeit - revizori szaktanácsadói vélemény adatai alapján - a számlázási kapcsolatuk szerint rendeztem (3. ábra). Az átstrukturálás során már kivehetővé vált számomra a tankönyvi példákból is jól ismert „körhinta” (kivastagított rész). Ennek felismerése azonban már kevésbé evidens összetett alakzatoknál.

$\mathrm{Az}$ ismertetett kapcsolati ábrák, valamint más határokon átnyúló, szervezett áfacsalások nyomozása tükrében találónak tûnik számomra Tóth Mihály egyetemi professzor idézete, miszerint: „A gazdasági bűnözés gyakran száraz és nehéz világa, soha nem izgalmasságával, lobogásával, inkább bonyolultsága, összetettsége miatt jelent számunkra kihívást." ${ }^{8}$

\section{A karusszel típusú csalás elleni fellépés eszköztára}

A szakirodalom, illetve a gyakorlat számtalan módját ismeri annak, hogy a hatóságok megnehezítsék az elkövetők dolgát e komplex csalási folyamat megvalósítása során. Ahelyett azonban, hogy elvesznénk ezeknek a fellépési eszközöknek „fegyvereknek” a sokaságában, a továbbiakban a nemzeti adó- és vámhivatali hatóságok által alkalmazott „fegyvernemekre”, valamint azok „célpontjaira”, azaz a karusszelek múködési mechanizmusát meghatározó és felszámolandó, illetve befolyásolandó releváns elemeire fókuszálok.

Amennyiben a Nemzeti Adó- és Vámhivatal fő szakterületeit a karusszel típusú csalás és más bűnügyi relevanciájú cselekmények elleni fellépés kontextusában vizsgáljuk, célszerú az adózók jogkövetési hajlandóságából kiindulni. Eszerint megkülönböztethetünk:

1. Tisztességes adózókat: Az adózók többsége bevallja és befizeti az adóját. Esetükben elegendő az adóigazgatás „fegyverneme”, amely segít számukra eligazodni az „adózás útvesztőjében”, azaz abban, hogy az ezzel kapcsolatos jogaikat érvényesíteni és kötelezettségeiket teljesíteni tudják.

2. Olyan adózókat, akik hajlamosak letérni a jogkövetés útjáról: Az adózóknak ez a csoportja is alapvetően tisztességes, azonban csak addig a pontig, ameddig érzik magukon az adóhatóság presszióját. Őket a speciális technikai eszközök - például online pénztárgépek vagy EKÁER-rendszer - segíthetik a jogkövetésben, amelyekkel a hatóságok nemcsak a bevallás időpontjában, hanem azt megelőzően is releváns információkat szerezhetnek.

Tóth (2018) 11. 
3. Haszonhúzókat, akik szándékosan nem fizetik meg az adót: Az adózóknak ezt az úgynevezett „állhatatos kisebbségét” sok esetben nem is lehet megszólítani az adózási és rendészeti módszerekkel, hiszen nem hordozzák magukon azokat az ismérveket, amelyek alapján kiválaszthatók lennének az ellenőrzések során, és gyakran strómanokkal leplezik tevékenységüket. Az eljárás alá vonásukhoz bünügyi eszközök szükségesek. ${ }^{9}$
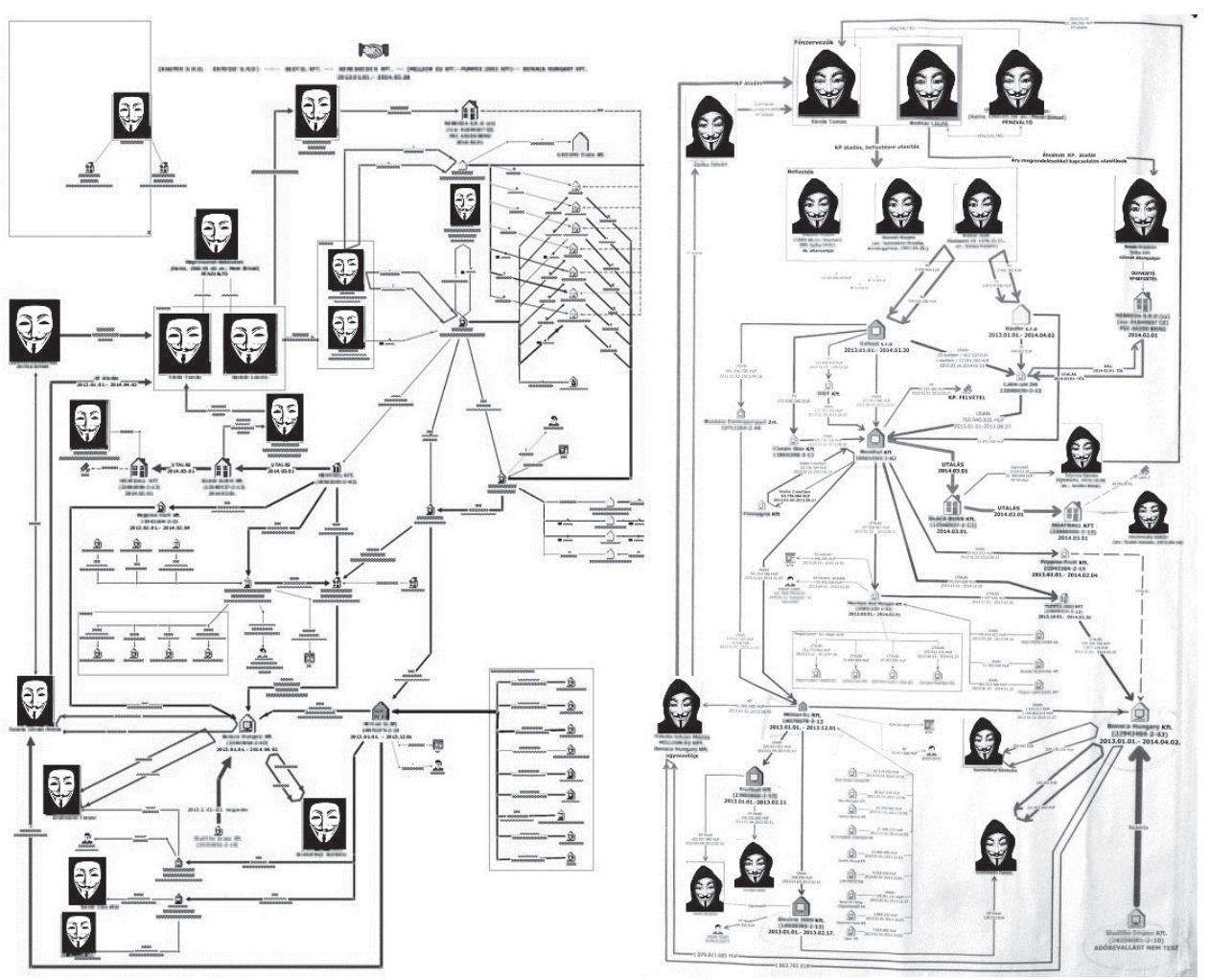

2. ábra: „Nyers” anonimizált kapcsolati ábra egy konkrét karusszel típusú csalási büntetôügyben. Forrás: Az ábrát e publikációban történő felhasználás céljából digitalizálta és anonimizálta Zierer Csaba a Nemzeti Adó-és Vámhivatal Bünügyi Föigazgatósága Központi Nyomozó Főosztály fôttörzszászlósa, bünügyi technikusa (2019) 


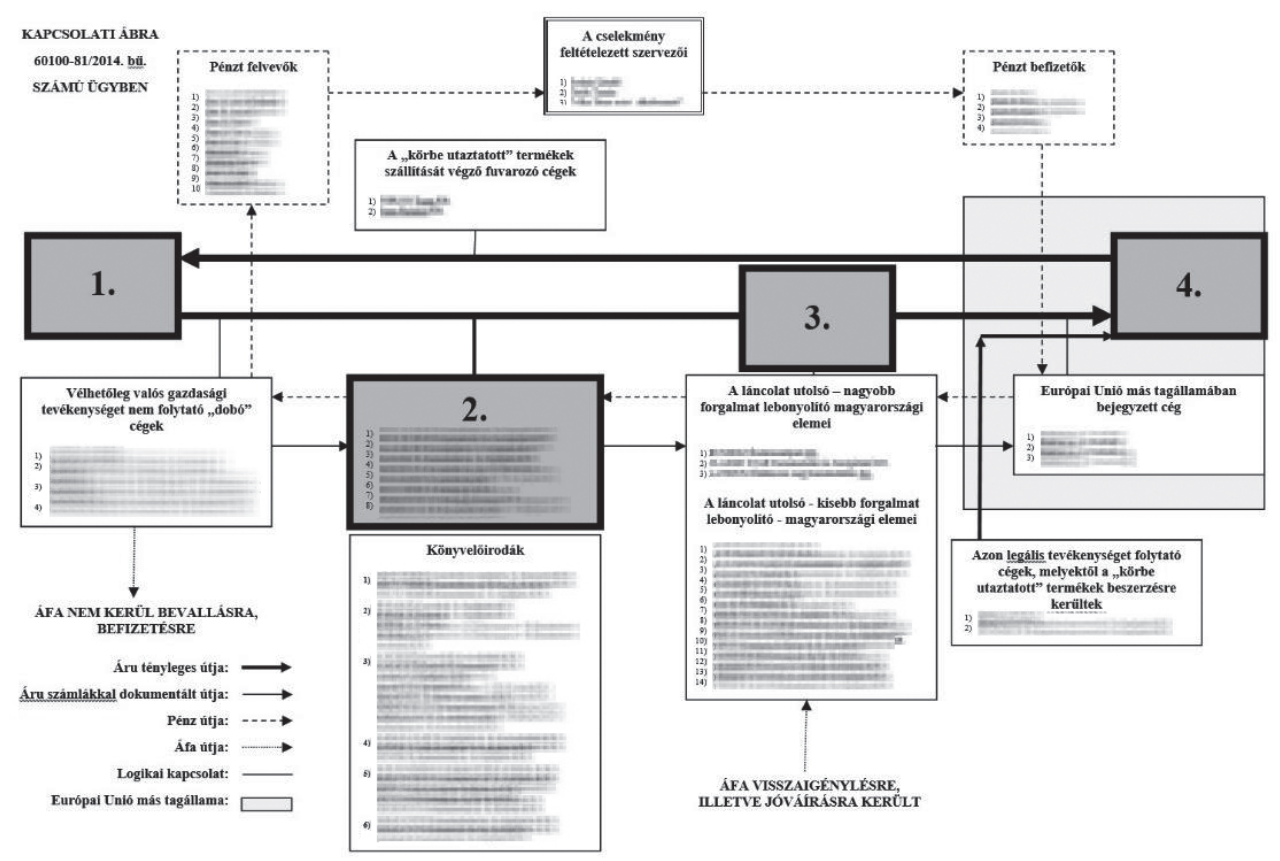

3. ábra: A 2. ábrán bemutatott karusszel típusú csalási büntetöügyben érintett gazdasági társaságok számlázási láncolatban elfoglalt helyük szerinti rendezéssel készített anonimizált kapcsolati ábra. Forrás: digitalizálta és anonimizálta Zierer Csaba, a szerző saját szerkesztése a 2. ábra alapján.

Megjegyzés: 1. Missing Traderek, 2. Bufferek, 3. Brokerek, 4. Comduitok

Habár e csalástípus elsősorban bünügyi kompetenciába tartozik, megelőzésük, felderítésük során az adóigazgatási és a rendészeti eszközöknek is jelentős szerepük van.

Mint ahogyan az 1. táblázat szemlélteti, a fellépés eszköztárát egy másik dimenzió, a karusszelcsalás müködési mechanizmusának releváns elemei alapján is célszerű lehet rendezni úgy, hogy az egyes elemeihez mint „célpontokhoz” azok felszámolására vagy befolyásolására alkalmas adóigazgatási, rendészeti és bűnügyi módszereket rendeljük hozzá. A „karusszelek” működési mechanizmusának fő jellemzői véleményem szerint az alábbiakban határozható meg:

1. Az elkövetési magatartás több tagállamot is érint.

2. A csalás résztvevői számlázási és árukapcsolati láncolatokkal „karusszeleket” építenek ki.

3. Az így létrehozott láncolat célja - a héa/áfa működési mechanizmusával történő visszaéléssel - a költségvetésnek történő vagyoni hátrány okozása.

4. A „körhintákat” az elkövetők bűnös szándékkal hozzák létre. 
5. A csalás résztvevői a költségvetésnek történő vagyoni hátrány okozásának szándékán túl más, szubjektív tudattartalommal - például piaci részesedés növelése, magasabb jövedelem és életszínvonal elérése - is rendelkeznek.

1. táblázat: A karusszel típusú csalás elleni fellépés célja; adóigazgatási (adópolitikai), rendészeti, és bünügyi eszközei, az elkövetési magatartásának föbb ismérvei tükrében.

Forrás: a szerző szerkesztése

\begin{tabular}{|c|c|c|c|c|}
\hline \multirow[b]{2}{*}{$\begin{array}{l}\text { A karusszel típusú } \\
\text { csalás releváns } \\
\text { elemei }\end{array}$} & \multirow[b]{2}{*}{$\begin{array}{l}\text { A karusszel típusú } \\
\text { csalás elleni } \\
\text { fellépés célja }\end{array}$} & \multicolumn{3}{|c|}{ A karusszel típusú csalás elleni fellépés föbb eszközei } \\
\hline & & $\begin{array}{l}\text { Adóigazgatási } \\
\text { (adópolitikai) } \\
\text { eszközök }\end{array}$ & $\begin{array}{l}\text { Speciális technikai } \\
\text { eszközök }\end{array}$ & Bünügyi eszközök \\
\hline $\begin{array}{l}\text { Az elkövetési ma- } \\
\text { gatartás több tag- } \\
\text { államot is érint. }\end{array}$ & $\begin{array}{l}\text { Nemzetközi együtt- } \\
\text { müködés megvaló- } \\
\text { sítása. }\end{array}$ & EUROFISC & - & $\begin{array}{l}\text { Europol (SIENA, EIS), OLAF, } \\
\text { Eurojust, EHI, eljárási jogse- } \\
\text { gély, európai elfogatóparancs } \\
\text { és kiadás, európai nyomozási } \\
\text { határozat, közös nyomozó } \\
\text { csoportot. }\end{array}$ \\
\hline $\begin{array}{l}\text { A csalás résztvevői } \\
\text { számlázási és áru- } \\
\text { kapcsolati láncola- } \\
\text { tokkal „karussze- } \\
\text { leket" építenek ki. }\end{array}$ & $\begin{array}{l}\text { E láncolatnak a fel- } \\
\text { térképezése és azon } \\
\text { pontjainak a beazo- } \\
\text { nosítása, ahol az áfát } \\
\text { nem vallották be, } \\
\text { vagy nem fizették } \\
\text { meg. }\end{array}$ & $\begin{array}{c}\text { VIES, Összesítő } \\
\text { nyilatkozat, bel- } \\
\text { földi összesítő } \\
\text { jelentés, megkere- } \\
\text { sés során bekért } \\
\text { bankszámlakivona- } \\
\text { tok, tanúk meghall- } \\
\text { gatása } \\
\end{array}$ & $\begin{array}{l}\text { Online adatszolgál- } \\
\text { tatási kötelezettség, } \\
\text { EKÁER. }\end{array}$ & $\begin{array}{l}\text { Adatkérés során bekért } \\
\text { bankszámlakivonatok, tanúk } \\
\text { kihallgatása, leplezett eszkö- } \\
\text { zök alkalmazása. }\end{array}$ \\
\hline $\begin{array}{c}\text { A láncolat cél- } \\
\text { ja - a héa/áfa } \\
\text { müködési me- } \\
\text { chanizmusával } \\
\text { történö vissza- } \\
\text { éléssel - a költség- } \\
\text { vetésnek történö } \\
\text { vagyoni hátrány } \\
\text { okozása. }\end{array}$ & $\begin{array}{l}\text { Az elkövetők „moz- } \\
\text { gásterének” korlá- } \\
\text { tozása. }\end{array}$ & $\begin{array}{c}\text { Héakulcsok harmo- } \\
\text { nizálása, fordított } \\
\text { adózás bevezetése }\end{array}$ & - & - \\
\hline $\begin{array}{c}\text { A körhintákat } \\
\text { az elkövetők bünös } \\
\text { szándékkal hozzák } \\
\text { létre. }\end{array}$ & $\begin{array}{l}\text { E láncolatot alko- } \\
\text { tó szereplők bűnös } \\
\text { szándékának a fel- } \\
\text { ismerése. }\end{array}$ & $\begin{array}{c}\text { Adóregisztrációs } \\
\text { eljárás, preventív } \\
\text { ellenőrzés, haté- } \\
\text { kony kockázat- } \\
\text { elemzés, fokozott } \\
\text { felügyelet, adószám } \\
\text { felfüggesztése } \\
\text { és törlése } \\
\end{array}$ & - & $\begin{array}{l}\text { Leplezett eszközök alkalma- } \\
\text { zása. }\end{array}$ \\
\hline $\begin{array}{l}\text { A csalás résztvevői } \\
\text { a költségvetésnek } \\
\text { történő vagyoni } \\
\text { hátrány okozásá- } \\
\text { nak szándékán túl } \\
\text { más, szubjektiv } \\
\text { tudattartalommal } \\
\text { is rendelkeznek. }\end{array}$ & $\begin{array}{l}\text { Jogkövetésre törté- } \\
\text { nő motiválás vagy } \\
\text { az elkövetéstől való } \\
\text { elrettentés. }\end{array}$ & $\begin{array}{l}\text { Adóbírság foko- } \\
\text { zása, biztosítási } \\
\text { intézkedés, ideig- } \\
\text { lenes biztosítási } \\
\text { intézkedés. }\end{array}$ & $\begin{array}{l}\text { A rendészeti fel- } \\
\text { lépés eszköztárának } \\
\text { a bővítése és hatéko- } \\
\text { nyabbá tétele. }\end{array}$ & $\begin{array}{l}\text { Büntetési tétel növelése, } \\
\text { búncselekményből származó } \\
\text { vagyon elvonása. }\end{array}$ \\
\hline
\end{tabular}


A továbbiakban az 1. táblázatban feltüntetettek közül két aktuális és meghatározó „fegyvert” szeretnék kiemelni, az általános fordított adózást - amely nem mindenben azonos a magyar joggyakorlatban alkalmazott fordított adózással - és a büncselekményből származó vagyon elvonását.

A fordított adózás azt jelenti, hogy a hatálya alatt álló adóalanyok - a héa múködési mechanizmusából eredendő visszaélések, elsősorban a karusszel típusú csalások elkerülése céljából - nem hárítanak át áfát egymásra, vagyis a számlát áfa felszámítása nélkül állítja ki az eladó, az adót pedig a vevő fizeti meg a költségvetés részére. Az Európai Unió Tanácsa 2018. október 2-án fogadta el azt a héairányelv-módosítást, amely szerint a tagállamok belföldi adóalanyok közötti - ügyletenkénti 17500 euró feletti öszszegű - értékesítésekre, átmeneti jelleggel (egyelőre azonban csak bizonyos gazdasági ágazatokban) 2022. június 30-áig előírhatják az általános fordított adózás alkalmazását, amennyiben az alábbi feltételek teljesülnek:

1. a tagállam héabevétel-kiesése legalább 5\%-kal meghaladja az uniós kiesés medián értékét,

2. a héabevétel-kiesés $25 \%$-át körhintacsalás okozza, és

3. a hagyományos intézkedések nem elegendők a fentiek megfékezésére. ${ }^{10}$

Megjegyzendő, hogy nagyon kevés számítás áll rendelkezésre a tekintetben, hogy mekkora a héacsalásokkal okozott kár összege az Európai Unióban. ${ }^{11}$ Az Európai Bizottság 2019. szeptember 5-én közzétett tanulmánya alapján ez a szám 137 milliárd eurót tett ki 2017-ben. ${ }^{12}$

Nem általános jelleggel ugyan, de az egyes gazdasági szektorokban a fiktív adóalanyok által elkövetett visszaélések kiküszöbölése érdekében Magyarországon már 2006. január 1. napján bevezették a fordított adózást, amely először a hulladékkereskedelmet érintette, majd további ágazatokra is (mint például építőipar, gabonakereskedelem stb.) kiterjesztettek. $^{13}$

A másik fellépési eszköz - amelynek kiemelését szükségesnek tartottam - a büncselekményból származó vagyon elvonása. Napjainkban uralkodó nézet szerint ugyanis a gazdasági bűnözés elleni küzdelem hatékonysága nem a kiszabható szabadságvesztés éveinek számával, hanem e profitorientált bűnözési forma rentabilitásának csökkentésével, nyereségességének fokozatos megszüntetésével, vagyis a bűncselekményből származó vagyon elvonásával növelhető. ${ }^{14}$ Ennek megfelelően a Nemzeti Adó- és Vámhivatal nyomozó hatósági feladatait ellátó szerveinek egyik fő stratégiai célkitűzése az elkövetők vagyonának felkutatása, illetve a büncselekményből származó vagyon lefoglalásával, zár alá vétellel, valamint önkéntes megtérítéssel való biztosítása. ${ }^{15} \mathrm{~A}$ vagyon elvonásának

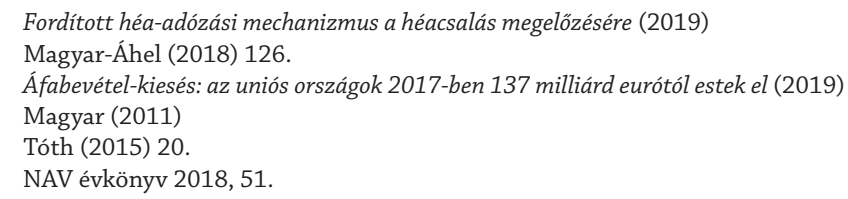


koncepciója azonban nemcsak bủnügyi, hanem adóigazgatási kontextusban is értelmezhető úgy, mint az adóigazgatási rendtartásról szóló 2017. évi CLI. törvény 82-83. §-ban meghatározott biztosítási vagy ideiglenes biztosítási intézkedés, amelyek célja, hogy az eljárás tárgyát képező kötelezettség teljesítését - mint például az adóbírság lerovását - az adózó ne hiúsíthassa meg.

\section{A karusszel típusú csalás búnügyi statisztikákban történő mérésének szülkségessége}

A karusszel típusú csalások elleni fellépés hatásainak vizsgálatakor költségvetési és bűnügyi statisztikai adatok nyújthatnak segítséget, amelyek közül véleményem szerint

1. az áfabevétel aránya a költségvetés bevételéből,

2. az ismertté vált héa/áfa és karusszel típusú csalások elkövetési értékeinek alakulása, illetve

3. a bűncselekménnyel okozott kár megtérülésének, azaz a vagyonbiztosításnak az aránya.

Ezek a legfontosabbak, hiszen a segítségükkel kaphatunk objektív és árnyalt képet e csalárd magatartásról a fenti szempontok szerint történő értékelésük során.

A Központi Statisztikai Hivatal által vezetett egységes nyomozó hatósági és ügyészségi bűnügyi statisztikából (ENyÜBS) - amely többek között a nyomozó hatóságok által indított és lefolytatott büntetőeljárások adatait tartalmazza - valamint a Nemzeti Adó- és Vámhivatal által évkönyvek és más tájékoztatók formájában közzétett kimutatások alapján azonban - mint ahogyan a 2. táblázatból is kitűnik - nem különíthető el az ismertté vált költségvetési csalások elkövetési értékéből, illetve a hatáskörös bűncselekmények kárbiztosítási mutatójából az áfa és a karusszel típusú csalások részaránya.

2. táblázat: Az ismertté vált költségvetési csalások bünügyi statisztikája 2015-től 2018-ig millió Ft-ban. Forrás: a szerző szerkesztése

\begin{tabular}{|c|c|c|c|c|}
\hline $\mathbf{E} \mathbf{v}$ & $\begin{array}{c}\text { Központi költségvetés } \\
\text { bevétele }^{16}\end{array}$ & $\begin{array}{c}\text { Központi költségvetés } \\
\text { áfabevétele }^{\mathbf{1 7}}\end{array}$ & $\begin{array}{c}\text { Ismertté vált költség- } \\
\text { vetési csalások elkövetési }^{\text {értéke }}{ }^{\mathbf{1 8}}\end{array}$ & $\begin{array}{c}\text { Kárbiztosítás a NAV hatás- } \\
\text { körébe tartozó büncselek- }^{\text {mények tekintetében }}{ }^{19}\end{array}$ \\
\hline $\mathbf{2 0 1 5}$ & 11826113 & 3285700 & 68372 & 30700 \\
\hline $\mathbf{2 0 1 6}$ & 12404501 & 3290293 & 40088 & 33500 \\
\hline $\mathbf{2 0 1 7}$ & 13087397 & 3525270 & 57778 & 42600 \\
\hline $\mathbf{2 0 1 8}$ & 13593984 & 3928686 & 42212 & 46900 \\
\hline
\end{tabular}

\footnotetext{
16 A központi költségvetés bevételei és egyenlege (2019)

17 A központi költségvetés bevételei és egyenlege (2019)

18 Bünügyi Statisztikai Rendszer (2019)

19 NAV évkönyv 2015, 55.; NAV évkönyv 2016, 55.; NAV évkönyv 2017, 49.; NAV évkönyv 2018, 51.
} 
Az áfa és a körhintacsalások önálló statisztikai mérésének további jelentősége az általános fordított adózási mechanizmus bevezetése kapcsán is felmerülhet, ugyanis - többek között - annak feltétele az, hogy a tagállam körhinta, és más héa-/áfacsalásokkal okozott bevételkiesése egy bizonyos értéket meghaladjon. Ennek megállapításához viszont megfelelő részletességű számszerűsített kimutatások nélkülözhetetlenek.

\section{Következtetések}

A hozzáadottérték-adót (héa) - amelyet a magyar terminológiában általános forgalmi adóként (áfa) ismerünk - Franciaországban vezették be először 1954-ben, majd számos előnyeire való figyelemmel alkalmazásuk világszerte elterjedt. Működési mechanizmusa azonban a tagállami határokat átlépő ügyletek tekintetében visszaélésekre ad lehetőséget, kihívást okozva ezzel a hatóságok számára, ugyanis az Európai Unió területén „héa nélkül keringő” áruk több mint 150-200 milliárd euró nagyságrendű bevételkiesést okoztak évenként az utóbbi időben.

A héavisszaéléseknek az egyik alaptípusa a karusszel típusú csalás, amely elleni fellépés célja lehet fő jellemzőinek - mint „célpontoknak” - adóigazgatási, rendészeti és bűnügyi „fegyvernemekkel” történő felszámolása, befolyásolása (1. táblázat). A cselekmény jellegét tekintve ezek közül az eszközök közül elsősorban a bűnügy meghatározó, azonban megelőzésük és felderítésük során adóigazgatási- és rendészeti módszereknek is jelentős szerepük van.

Az egyes „fegyverek közül” érdemes kiemelni az Európai Unióban a közelmúltban ideiglenesen bevezetett általános fordított adózást, amely mechanizmusa lényegesen korlátozhatja az elkövetők mozgásterét; valamint a bűncselekményből származó vagyon elvonásának szükségességét, hiszen napjainkban uralkodó nézet szerint az anyagi haszonszerzés által motivált gazdasági bűnözés elleni küzdelem hatékonysága legfőképpen ezzel növelhető.

Fontosnak tartom továbbá a karusszel típusú csalások búnügyi statisztikákban történő mérésének indokoltságát hangsúlyozni, hiszen segítségükkel objektív képet kaphatunk a hatósági intézkedések szükségességéről és eredményességéről; valamint kimutatásuk relevanciája az általános fordított adózási mechanizmus bevezetése kapcsán is felmerülhet, ugyanis annak feltétele bizonyos - héa-/áfacsalással, illetve ezen belül körhintacsalással okozott bevételkiesést mutató - mérőszámoknak a teljesülése.

\section{IRODALOMJEGYZÉK}

James, Kathryn (2011): Exploring the Origins and Global Rise of VAT. In Bergin, Christopher eds.: The VAT Reader. Washington, Tax Analysts. DOI: https://doi.org/10.2139/ssrn. 2291281

Lámfalusi Ibolya - Tanító Dezső szerk. (2013): A mezőgazdasági és az élelmiszeripari termékekre vonatkozó áfarendszer és -mérték változása és hatásai. Budapest, Agrárgazdasági Kutató Intézet. 
Magyar-Áhel Eszter (2012): Szervezett áfacsalások az Európai Unióban. In Csete Rita - Magyar-Áhel Eszter - Magyar Csaba - Sándor Zsolt: EU és az ellenörzési szakterület. Budapest, Nemzeti Adóés Vámhivatal Képzési, Egészségügyi és Kulturális Intézete Adóügyi Iskola. 85-99.

Magyar-Áhel Eszter (2018): Áfacsalások az Európai Unióban. In Szabó Andrea szerk.: Pénzügyi nyomozói kézikönyv. Budapest, Dialóg Campus Kiadó. 123-136.

Tóth Mihály (2015): A gazdasági bünözés és büncselekmények néhány aktuális kérdése. Budapest, Magyar Tudományos Akadémia.

Tóth Mihály (2018): A gazdálkodással összefüggő bűncselekmények - egy kriminológiai gyufásdoboz oldalai, vagy lángra lobbanni képes gyufaszálak is? In Domokos Andrea szerk.: A gazdálkodással összefüggő büncselekmények büntetőjogi értékelése konferencia előadásainak szerkesztett változata. Budapest, Károli Gáspár Református Egyetem Állam- és Jogtudományi Kar. 11-24.

Vankó László (2017): Az adózás kriminalizálása és annak aktualitásai. In Domokos Andrea szerk.: A költségvetés büntetôjogi védelme konferencia elöadásainak szerkesztett változata. Budapest, Károli Gáspár Református Egyetem Állam- és Jogtudományi Kar. 73-80.

\section{Internetes források}

Áfabevétel-kiesés: az uniós országok 2017-ben 137 milliárd eurótól estek el (2019). Sajtóközlemény. Forrás: https://ec.europa.eu/commission/presscorner/detail/hu/ip_19_5511 (2019. 09. 22.)

A központi költségvetés bevételei és egyenlege (2019). Forrás: www.ksh.hu/docs/hun/xstadat/xstadat_ evkozi/e_qse006j.html?down=199 (2019. 08. 30.)

Bủnügyi Statisztikai Rendszer (2019). Forrás: https://bsr.bm.hu (2019. 08. 30.)

Bokor Adrienn (2017): Hozzáadottérték-adó reform az Európai Unióban. Forrás: https://adozasitanacsadas.hu/tagianyag/7734/dr-bokor-adrienn-hozzaadottertek-ado-reform-az-europai-unioban (2019. 08. 18.)

Fordított héa-adózási mechanizmus a héacsalás megelözésére (2019). Forrás: www.consilium.europa.eu/ hu/policies/vat-reverse-charge/ (2018. 08. 14.)

Magyar Szilvia (2011): Fordított adózás szabályai. Forrás: www.jogiforum.hu/hirek/26304 (2019. 08. 23.)

NAV évkönyv 2015. Forrás: https://nav.gov.hu/data/cms404657/NAV_Evkonyv_2015_CD.pdf

NAV évkönyv 2016. Forrás: https://nav.gov.hu/data/cms436895/NAV_evkonyv_2016.pdf

NAV évkönyv 2017. Forrás: https://nav.gov.hu/data/cms479562/NAV_evkonyv_2017.pdf

NAV évkönyv 2018. Forrás: www.nav.gov.hu/data/cms496584/NAV_evkonyv_2018.pdf

\section{ABSTRACT}

\section{Branches and Targets of Carousel Fraud Schemes}

SZABÓ Barna

Carousel fraud is one of the basic schemes of cross-border organised VAT the fight against it became current, and it is at the same time a challenge for the National Tax and Customs Administration and its predecessors. This article aims to introduce this fraud scheme and the tax administration-, law enforcement- and criminal investigation toolkits ('branches') used in combating it, and to allocate each tool ('arms') to the efforts ('targets') made to eradicate the relevant elements characterising the working mechanism of carousel fraud. Additionally, I also intend to point out the necessity of measurement of carousel fraud in criminal statistics, the relevance of which, in addition to the general feedback, lies in the application of general reverse taxation implemented in the EU on a temporary basis not long ago.

Keywords: carousel fraud, general reverse taxation, property insurance, criminal statistics 